\title{
Values Investment Models of Multicultural Education in Yayasan Sultan Iskandar Muda Medan
}

\author{
Tenni Oktaviana Sipayung, Setyabudi Indartono, Taat Wulandari
}

\begin{abstract}
This study aims to describe the values investment of models multicultural education among students. The focus of the problem related to the implications of the investment of the values multicultural education against the attitude of tolerance as well as curriculum and instruction implementation of planting multicultural education values towards tolerance and curriculum and teaching applied to students. The method used in this study is a qualitative method with a case study approach. The results of the study illustrate that multicultural values via integrated subjects is sociology, social sciens eduation, PPKn, religion, history and other supports with the models of a multicultural approach to forming study groups, the seating arrangements that blend with each other as we provide a place of worship for every students so that each student can appreciate people different from himself.
\end{abstract}

Keyword: Multicultural Education; Social Studies

\section{INTRODUCTION}

Education gives the significance in the development process as well as the progress of a nation. Education also plays a role in shaping public life which is believed to able to provide a significant role in shaping the cultural and politic. Therefore, education as one of media in setting up and forming a social life can become the base of educational institutions that are loaded will values idealism. To foster harmony among the cultural differences, then the education that puts the understanding of the importance of the students to realize that mutually tolerant behave, respect, appreciate, understand each other it was very important. Multicultural education is an educational strategy which applicated into all kinds of subjects which accommodate cultural differences on learners. Such as ethnic origin, religion, language, gender, social class, ability and age (Banks, James, A, 2008). In order for the process of learning to be more effective and easy, also needed to build the character of the students to behave in a democratic, humanist and pluralis in their environment. Multicultural education should facilitate the teaching and learning process that changes the perspective multiculturalis who value diversity and difference, and tolerant attitude open (inclusive). The application of multicultural education in school sometimes are indeed very has not been heeded, particularly on learners. If the application actually understood mutual tolerance, respect and respect it is very important, both in the environment of the learners or the teacher's council on the environment. Therefore, the multicultural education for learners is very urgent to be encouraged as a foundation for community development of Indonesia a more open, tolerant, and democratic.

Revised Manuscript Received on August 14, 2019.

* Correspondence Author

Tenni Oktaviana Sipayung*, The Author is currently studying in postgraduate social sciens education at Yogyakarta State University.

Setyabudi Indartono, Ph.D., Assoc. Prof. in Human Resources Management, Dept. Head of Management School, Yogyakarta State University.

Dr. Taat Wulandari, M.Pd. Postgraduate Lecture in Yogyakarta State University.

(C) The Authors. Published by Blue Eyes Intelligence Engineering and Sciences Publication (BEIESP). This is an open access article under the CC BY-NC-ND license (http://creativecommons.org/licenses/by-nc-nd/4.0/)
The most prominent power in the multicultural education on students is how they receive the difference as a reasonable, and stressed the importance of education to fight for the religiosity and realizing value universal among students without discriminating of religion and belief. Grant \& Sleeter (Banks, 2005:64) explains that race, class and gender in regular use the basis for forming groups of people in society. A teacher who failed to integrate racial, social class, and gender may result in the presence of the wrong understanding of what is happening in school, even leading to the understanding that it is not right for justice education. Yayasan Perguruan Sultan Iskandar Muda the school is aiming to realize a multicultural education. Multicultural education model is applied in all schools are expected to help much and improve conditions of society Indonesia are heterogeneous and the vulnerable will be the appreance of a conflict. Based on the background of the issue, this research aims to describe the model of multicultural education held at the school Yayasan Perguruan Sultan Iskandar Muda. School of Yayasan Perguruan Sultan Iskandar Muda make the school as a miniature society with full of colourful culture, designed a multicultural education curriculum that is expected to reduce the variety of factors arising out of the individual one another varies. Multicultural education curriculum developed at the school Yayasan Perguruan Sultan Iskandar Muda can be applied to other schools is indeed in accordance with the community's different ethnic, language, culture and socioeconomic status also..

\section{LITERATURE REVIEW}

\section{A. VALUES}

Sowing is the process works and how to build. While the value is itself a translation of the word value that is derived from Latin valere or language of ancient France valoir which can be meant as a price. The value of things or things that are assessed or the result of interaction between a subject and object appraised rate or the result of the interaction of the two or more variables. Meanwhile, Kluckohn (Mulyana) defines value as the conception (implied or expressed, that nature differentiates individual or group chracteristics) of what is desirable, that affect the options on the way, the purpose and the end action. Thus, the values means something metaphysical, though with regard to concrete reality. We can see no value in physical form, for value pricing is something to look for in the human process of responding to human attitude that order more value with regard to the good that exists in the core of a thing. So the value is a positive relationship between the level of something with a particular person. Among other things, the practical value, social value, aesthetic, value, cultural values, religious values, moral values or morals.

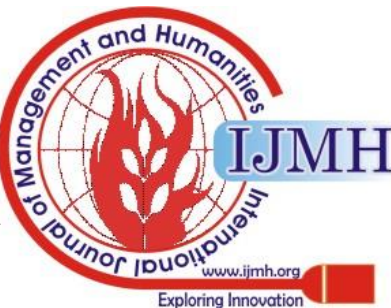


Of some value above definition there is one intersection which mentions that the value is something that is in invisible. However, there appears to be a form of this value are not making a value that doesn't exist, because the value is always inherent in everything that is around humans. Refer Bertens (2005:141), the values have the following characteristics:

1. The value associated with the subject, if there is no subject that rate them there is no value.

2. The value present in something practical context, where the subject want to make something.

3. The values contain properties that are "added" by the subject on properties owned by the object.

\section{B. MULTICULTURAL EDUCATION}

Multicultural is cultural diversity. Etymologically, the term multiculturalism is formed from the word multi (a lot), culture and ism. As for the intrinsically, in the words of multiculturalism that contained recognition of human dignity that lived in his community with each culture is unique. Whereas, culture itself unbiased released from four important themes, namely religion (flow), race (ethnicity) tribes and cultures. This means that discussion of multicultural includes not only cultural differences but also entrance inside compound religion, racial or ethnic. Multiculturalism is also a concept in which a community can recognize the nationality in the context of diversity, difference and cultural pluralist, good race, tribe, ethnicity and religion. A concept that gives our understanding that a plural or plural nation is a nation that is filled with diverse cultures or multicultural. Thus the multicultural paradigm te. give lessons to us to have an appreciation of and respect for the culture and other religions.

In the meantime, if the multicultural paradigm is brought to the realm of education, which later gave rise to the term $\mathrm{d}$. multicultural education can be understood as education for people of color. It means education in it there is a wide range of human, or education that are shown to see the diversity of human beings, or more than that of education trying to see and then addressing the realities of the diversity that exists in man either individually or as a social creature. Also, the multicultural education means the creation of individuals who are aware of the existence of the pluralism culture of which there are many differences and respect the diversity that exists to realize the harmony and peace. So is the cultivation of the values of multicultural education here is the process of embedding something at stake community associated with a particular view or the abstraction that is considered good or bad. In this case the abstraction usually with education considering seriously the background of the learners both in terms of race, ethnicity, tribe, culture or religion.

\section{IMPORTANCE OF MULTICULTURAL}

Multicultural education is an urgency for education in Indonesia. Multiculrual education needs to be given to every level of education ranging from elementary level education to high level education which is currently being implemented in several schools that will be the focus of this research. Recognition of the diversiy of Indonesia society has been explicit in writing on the Indonesian emblem.
Multicultural education in schools according to James A. Banks must be carried out comprehensively, not only fair attitudes among students who are different in religion, race ethnicity and culture, but also must be supported by a curriculum both written and coverst curriculum, integrative evaluation and teacher who have productive understanding, attitudes and actions in providing multicultural education services to their students.

In order to provide the best service for entire school client, the school must design, plan and control all elements of the school that can supports the multicultural education process well. Schools must plan learning processes that can foster multicultural attitudes of students so sthey can become members of a democratic society, respecting human rigths and justice. Schools must design learning processes, prepare curricula and design evaluations and prepare teachers who have multicultural perceptions, attitudes and behaviors, so that they become a part that contributes positively to the development of the students multicultural attitudes.

\section{THEORICAL PERSPECTIVE}

James A. Banks stating that the multicultural education has five interrelated dimensions, namely:

Content Integration, that of integrating different cultures and groups to illustrate the fundamental concepts, generalitations and theories in subjects or diciplines.

The Knowledge Construction Process, i.e bringing the students to understand, investigate, determine how involved the acceptance of various cultures, and the frame with which the perspective built a construction of new knowledge.

An Equality Pedagogy, i.e adjusting teaching methods by means of student learning in order to facilitate academic achievement of students who are diverse both in terms of race, culture or social starta.

Prejudice Reduction, namely the focus on characters and values of culture learners with which educators can modify his education.

e. An Empowering School Culture, that is done by trained group to participate in sports, interact with the entire staff and students of different ethnic, and race in an effort to create a culture of academic excellence. All five dimensions above the completion of multicultural education dimensions according to James A. Banks. For in writing before, mentioning that the dimensions of multicultural education is a content integration, knowledge construction area, an eguity pedagogy, an empowering school culture and the school a social system. The fifth dimension of this, James A. Banks then add the prejudice reduction and the previous opinion that incorporate points of the school as a system (the school a system). Likewise James A. Banks retain points the school a this system within the framework of multicultural education.

Multicultural education is possible in a formal educational institution should at least pay attention to existing systems. Based on the description above, it is understood that multicultural education not only requires thr involvement of educators, but all the components that are in the institution should be directed to the concept of multicultural education. As is the case with education policies, which should support the existence of the values of democracy, justice, equality and so forth that reflects the multicultural attitudes.

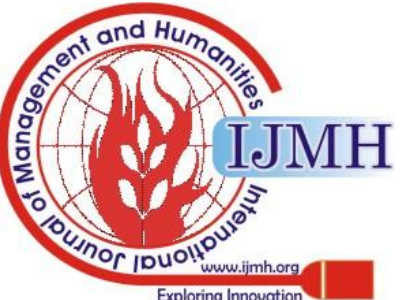




\section{METHODS}

This study uses qualitative methods. This method is in line with the objectives of this study, that is, to understand the situation in a multicultural educational practices in particular schools. The research took place at school with diverse learners both in terms of ethnicity, religion and culture. Research conducted at the school Yayasan Perguruan Sultan Iskandar Muda The selection of the place of research based on considerations which are relevant to the research objectives. Yayasan Perguruan Sultan Iskandar Muda is the school's field education carrying out multicultural. The rest of the citiziens Yayasan Perguruan Sultan Iskandar Muda terrain reflects cultural heterogeneity, such as ethnicity, religion, culture, customs and socioeconomic conditions. Subjects in the study were principals, teachers and students in school of Yayasan Perguruan Sultan Iskandar Muda.

\section{DISCUSSION \& RESULT}

\section{A. YAYASAN PERGURUAN SULTAN ISKANDAR MUDA}

Historically the Yayasan Perguruan Sultan Iskandar Muda was established on August 25, 1987 by Dr. Sofyan Tan. The name Sultan Iskandar Muda deliberately taken because is it the first Sultan of Aceh who did the first trade contacts with the Chinese. Yayasan Perguruan Sultan Iskandar Muda is located on the street T. Amir Hamzah pekan I Medan Sunggal, which organizes education from preschool level, elementary, junior high school, high school and vocational school. This school has a vision as follows:

1. No child may be excluded from school because it is not able to pay school fees.

2. A teacher who speaks ill of any religion or teachers impose a religion to the learners will be expelled from school.

3. A pupil who discriminate, either verbal or physical abuse towards his friend, teacher or other school citiziens will be subject to severe sanctions.

The vision of the school became very important because this vision which became a frame of refrence to make it happen. Incomprehension of what is multicultural values can become its own barriers to implementation of multicultural education.

\section{B. VALUES INVESTMENT}

The values of multicultural education in the transformation through to all subjects, such as sociology, social science education, PPKn, religion, history, and other supporting material. Realize that curriculum is one aspect of multicultural education has a role to nurture teachers in educating students in the classroom. Yayasan Perguruan Sultan Iskandar Muda (YPSIM) Medan develops curriculum and the learning model of the processed this multicultural, model of multicultural education during this run can be more systematic and structured. The discourse and practice of multicultural education in schools giving effect to the recognition of the diversity of society Indonesia. Supports the opinion of James A. Banks describes a multicultural education in schools needs to be done in a comprehensive manner, not only how the fair among students of different religious, racial, ethnic and cultural diversity, but also must be supported by good curriculum written and veiled, integrative evaluation and teacher who has understanding, attitudes, and actions that are productive in providing multicultural education service to each student.

\section{MODELS}

To provide the best reinforcement of multicultural, school design, plan and control the entire elements of the school which can support the process of multicultural education. Schools should plan the learning process that can foster an attitude of multicultural students to become a member of a democratic society, respect for human rights and justice. In addition to the need to set out to design the learning process, preparing the curriculum design, evaluation, and prepare teachers who have the perception, attitude, and behavior of multicultural, so that it becomes a part of contributing positively towards the construction of the attitudes of multicultural students. Value of multicultural practices undertaken Yayasan Perguruan Sultan Iskandar Muda (YPSIM) the terrain by creating a strategic model, such as discussion groups, multicultural setting the intermittent seating, giving material or doing activities that can increase the awareness of students about social issues, facilitating the development of an attitude of respect and respect for different religious between of the people by providing a place of worship of each religion to respect all students with each feast day. Thus equips the students to always think clarification of the relationship between life goals with reality and context of a diverse global world (Soeprapto, 2013:268).

\section{CONCLUSION}

Multicultural education model that was implemented in the school of Yayasan Perguruan Sultan Iskandar Muda (YPSIM) created through the vision and policies of the school. This creates the Foundation of culture to appreciate and accept the differences. The importance of commitment from all parties concerned is a way of implementing multicultural education. As for the strategic model made by multicultural discussion group, designed the seating arrangements are alternating in providing material or undertake activities that can increase the awareness of students about social problems. School of Yayasan Perguruan Sultan Iskandar Muda (YPSIM) have pupils with different religions and bridging the attitude of the citizens of the school who have religious diversity, ethnicity, and social class.

\section{REFERENCES}

1. Ahmad, Fedyano Saifuddin. 2004. "Multicultural Education: Putting School First, A Lesson from Education Autonomy Policy Implementation in Indonesia. Journal of Multicultural Education in Indonesia and Southeast Asia: Steeping into the Unfamiliar. DepokUI: Antropologi Indonesia.

2. Ainul, Yakin, M. 2005. Pendidikan Multicultural, Cross-Cultural Understaning untuk Demokrasi dan Keadilan. Yogyakarta: Pilar Media.

3. Al Arifin, Akhmad Hidayatul. 2012. Implementasi Pendidikan Multikultural Dalam Praksis Pendidikan di Indonesia. Jurnal Pembangunan Pendidikan, Vol 1 No. 1 Tahun 2012.

4. Banks, James, A. 2005. An Introduction to Multicultural Education. Boston: Person.

5. Banks, James, A. 2008. An Introduction to Multicultural Education Cetakan ke-4. Boston: Pearson.

Blue Eyes Intelligence Engineering \& Sciences Publication 
6. Hanum, Farida. 2015. Pentingnya Pendidikan Multikultural Dalam Mewujudkan Demokrasi di Indonesia. FIP: UNY.

7. Khoirunnisak, Mira. 2015. Nilai-Nilai Pendidikan Multikultural dalam Berbagai Kegiatan Sekolah di SMA Negeri 2 Sleman. Yogyakarta: UIN Sunan Kalijaga.

8. Miles, Matthew B. \& Huberman, A. Michael. 1992. Analisis Data Kualitatif (Penerjemah: Tjetjep Rohendi Rohidi). London: Sage Publication.

9. Pageh, I Made. 2016. Multikulturalisme dan Tantangannya di Indonesia: Jejak Kesetaraan Etnis dan Kultur. Journal Social Sciense Education Vol 3 (2) 115-125.

10. Raihani. 2011. Creating a culture of religious tolerance in an Indonesian School. Journal Multicultural of Education.

11. Rosyada, Dede. 2014. Pendidikan Multikultural di Indonesia Sebuah Pandangan Konsepsional. Jakarta: UIN Syarif Hidayatullah.

12. Rubin, Daniel Ian. 2017. From The Beginning: Creating a Diversity and Multicultural Education Course at Jacksonville State University. Journal education and Urban Society.

13. Saliman, Mukminan, Taat Wulandari. 2014. Model Pendidikan Multikultural di Sekolah Pembauran Medan. Cakrawala Pendidikan, Oktober 2014, Th. XXXIII, No. 3.

14. Suprapto, Sri. 2013. "Landasan Aksiologis Sistem Pendidikan Nasional Indoneisa dalam Perspektif Filsafat Pendidikan". Cakrawala Pendidikan (Jurnal Ilmiah Pendidikan, Th.XXXII, No. 2, hlm 266276.

15. Taylor, Charles. 1992. Multiculturalism and Politics of Recognition. Princeton: Princeton University Press.

\section{AUTHOR PROFILE}

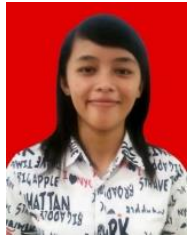

Tenni Oktaviana Sipayung. The Author is currently studying in postgraduate social sciens education at Yogyakarta State University. Email: tennioktaviana.2017@student.uny.ac.id

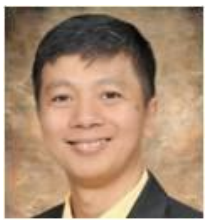

Setyabudi Indartono, Ph.D. Scopus Author ID: 37123968000, Assoc. Prof. in Human Resources Management, Dept. Head of Management School, Yogyakarta State University. Email: setyabudi_indartono@uny.ac.id.

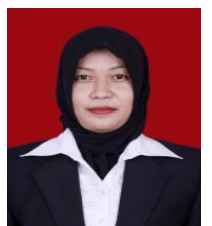

Dr. Taat Wulandari, M.Pd. Postgraduate Lecture in Yogyakarta State University. Email: taat_wulandari@uny.ac.id

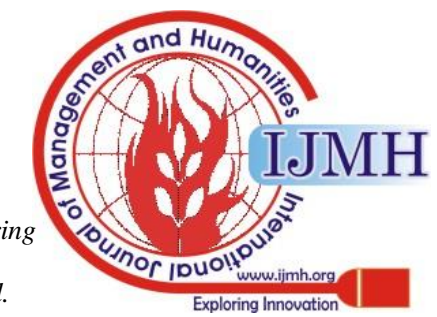

